\title{
SOSIALISASI PELESTARIAN PENCAK SILAT SEBAGAI WARISAN BUDAYA DAN SOFT POWER INDONESIA
}

\author{
Junita Budi Rachman ${ }^{1 *}$, Savitri Adityani ${ }^{1}$, Dadan Suryadipura ${ }^{1}$, Bima Prawira Utama ${ }^{1}$, \\ Sintia Catur Sutantri' ${ }^{2}$, Mohamad Rizky Novalini ${ }^{1}$ \\ ${ }^{1}$ Universitas Padjadjaran, Bandung, Indonesia \\ ${ }^{2}$ International Women University, Bandung, Indonesia \\ *junita@unpad.ac.id
}

\begin{abstract}
Abstrak: Pencak silat merupakan warisan nasional negara Indonesia yang perlu dikenal dan dilestarikan oleh generasi muda. Oleh karenanya, diperlukan upaya masif untuk mengenalkan pencak silat kepada generasi muda yang salah satunya melalui kegiatan sosialisasi. Kegiatan pengabdian kepada masyarakat ini berbentuk sosialiasasi yang bertujuan untuk memberikan pengetahuan dan pemahaman terhadap siswa sekolah menengah pertama tentang pentingnya pencak silat sebagai warisan budaya sekaligus sumber soft power Indonesia. Kegiatan ini juga bertujuan untuk mengetahui bagaimana penerimaan dan kesediaan untuk bertindak setelah sosialisasi kepada pelajar sekolah menengah pertama (SMP 2) Bandung. Dengan menggunakan model sosialisasi partisipatif dari Mead (1972), kegiatan pengabdian masyarakat ini dilakukan dalam empat tahap yaitu tahap persiapan (preparatory stage), tahap meniru atau bermain peran (play stage), tahap siap bertindak (game stage) dan tahap penerimaan target atas norma kolektif (generalized stage). Hasil penelitian dianalisis menggunakan metode kualitatif dengan deskripsi data statistik sederhana. Hasil sosialisasi menunjukkan bahwa siswa mendapatkan pengetahuan dan pemahaman yang baik mengenai pentingnya pencak silat sebagai warisan budaya Indonesia dan sebagai sumber soft power bagi negara Indonesia. Mayoritas siswa setuju untuk ikut berpartisipasi dalam mempromosikan pencak silat sebagai bentuk kesadaran dan tanggung jawab sosial mereka. Dengan demikian, kelestarian pencak silat sebagai warisan budaya Indonesia dan pencak silat sebagai sumber soft power Indonesia potensial untuk diwujudkan melalui para siswa sekolah menengah pertama sebagai generasi penerus.
\end{abstract}

Kata Kunci: Indonesia, pelestarian, pencak silat, soft power, warisan budaya

\begin{abstract}
Pencak silat is the national heritage of the Indonesian that needs to be known and preserved by the younger generation. Thus, massive efforts are needed to introduce pencak silat to the younger generation, one of which is through socialization activities. Socialization in the context of this community service program was carried out to junior high school students (SMP 2) Bandung aiming to provide knowledge and understanding of the importance of pencak silat as a cultural heritage and source of Indonesian soft power, as well as to find out how their reception and the willingness to act after socialization. By using the participatory socialization model from Mead (1972), the socialization consisted of four stages; preparatory stage, play stage, game stage, and generalized stage. The results of the program were analyzed using qualitative methods with the description of simple statistical data. The results of the socialization shows that students gained good knowledge and understanding about the importance of pencak silat as Indonesian cultural heritage and as a source of soft power for the Indonesian state. The majority of students agreed to participate in promoting pencak silat as a form of their awareness and social responsibility. Thus, the preservation of pencak silat as an Indonesian cultural heritage and pencak silat as a source of Indonesian soft power has the potential to be realized through junior high school students as the next generation.
\end{abstract}

Keywords: Indonesia, preservation, pencak silat, soft power, cultural heritage

\section{Pendahuluan}

Pencak silat merupakan seni beladiri asli bangsa Indonesia yang merupakan warisan budaya leluhur. Berawal dari tradisi di Sumatera Barat dan Jawa Barat, pencak silat berkembang 
ke seluruh wilayah Indonesia. Berbeda dengan seni bela diri lainnya, pada pencak silat Indonesia terkandung nilai-nilai dan kebijakan-kebijakan kearifan lokal, serta ritual-ritual budaya yang menuntun cara hidup yang positif. Keanekaragaman budaya daerah yang ada di Indonesia turut memberi warna yang memperkaya kandungan pencak silat Indonesia sebagai keunikan tersendiri (Gristyutawati, Purwono, \& Widodo, 2012).

Keunikan pencak silat dapat diurai dari empat aspek utama yang dimilikinya. Yang pertama adalah mental spiritual. Aspek ini membangun dan mengembangkan kepribadian luhur, karakter mulia dan sifat patriotik, keberanian, kedisiplinan dan juga ketaqwaan kepada Tuhan Yang Maha Esa dari seorang pesilat. Aspek yang kedua adalah budaya dan permainan seni pencak silat. Melalui gabungan serasi gerak seni tari dan gerak ancang kuda-kuda yang diiringi dengan musik tradisional untuk mengolah rasa dan estetika internal sekaligus olah konsentrasi, kesiagaan fisik dan pengendalian diri dalam menghadapi tantangan eskternal. Aspek ketiga, yaitu bela diri yang dilandasi dengan sikap kesatria. Dengan gerak yang terampil, tanggap dan tangkas untuk menjaga keselamatan diri dan melindungi sesama yang perlu dilindungi. Aspek keempat, pencak silat sebagai olahraga fisik, mental dan pikiran (Subroto \& Rohadi., 1996). Pengolahan raga yang terpola untuk mencapai kesehatan, kebugaran dan rekreasi sekaligus prestasi diri maupun kolektif bangsa yang diwakili. Selain itu, sebagai olahraga yang dikompetisikan pencak silat menjadi salah satu alat pemersatu nusantara, pengharum nama bangsa, dan pembentuk identitas bangsa dan negara Indonesia (Muhyi \& Purbojati, 2014). Semua elemen tersebut membuat pencak silat layak dinobatkan sebagai warisan budaya tak benda (Ediyono \& Widodo, 2019).

Pada Maret 2017 Pemerintah Indonesia mengajukan pengakuan pencak silat sebagai warisan budaya luhur Indonesia kepada The United Nations Educational, Scientific and Cultural Organization (UNESCO). Kemudian pada Kamis 12 Desember 2019 UNESCO di Bogota, Kolombia mengakui dan menetapkan pencak silat sebagai Warisan Budaya Tak Benda Dunia (Intangible Cultural Heritage) melalui sidang ke 14 Intergovernmental Committee for the Safeguarding of the Intangible Cultural Heritage (Welianto, 2020). Dengan adanya pengakuan internasional ini, pencak silat semakin meyakinkan sebagai suatu sumber kekuatan kemenarikan (soft power) tersendiri bagi negara Indonesia. Sumber-sumber soft power, seperti nilai-nilai, budaya dan keharmonisan (Nye, 2004) terrepresentasi di dalam pencak silat.

Sebagai soft power pencak silat perlu senantiasa dilestarikan dan diberdayakan oleh bangsa Indonesia melalui ragam caranya. Di antaranya adalah melalui perhelatan olahraga internasional. Pada Asian Games 2018 yang diadakan di Jakarta dan Palembang, pencak silat dihadirkan menjadi cabang olahraga (cabor) resmi yang dipertandingkan. Indonesia berhasil meraih peringkat keempat dalam peraihan jumlah medali berkat sejumlah medali emas yang didapat dari pencak silat. Hal ini berdampak terhadap meningkatnya popularitas pencak silat secara nasional dan internasional (Rachman, et al., 2019).

Asian Games 2018 yang telah mengangkat pencak silat sebagai sumber soft power Indonesia menjadi momentum bagi kebangkitan pencak silat. Sebagai implementasi legasi pasca Asian Games 2018, Pemerintah Indonesia berkomitmen agar pelestarian dan pemberdayaan pencak silat lebih digiatkan dan ditingkatkan (Kemenlu.go.id, 2019). Selain 
pencak silat difokuskan pada aspek olah raga/bela diri, pencak silat diarahkan menjadi bagian dari kurikulum seni dan budaya yang diajarkan pada sekolah dasar (SD) sampai tingkat sekolah selanjutnya. Melalui kurikulum pencak silat sebagai ilmu seni dan budaya mengajarkan tentang menjaga hubungan manusia dengan Tuhan, manusia dengan manusia, manusia dengan alam, dan dilatih dalam berbagai seni dan teknik olah mental, rasa dan fisik. Tujuannya adalah untuk meningkatkan kecerdasan emosional, kemampuan motorik, kemampuan mempertahankan diri, hidup sehat, membangun persahabatan dan berprestasi yang mengangkat nama negara. Dengan demikian pencak silat sebagai sikap dan amalan gaya hidup yang positif dan kepribadian yang khas bangsa Indonesia akan terjaga keberadaannya dan kelestariannya. Selain itu kontribusi pencak silat sebagai sumber soft power Indonesia akan terjamin (Kriswanto, 2015).

Namun tak dipungkiri popularitas pencak silat di Indonesia sempat menurun dan bersaing dengan beberapa seni bela diri yang datang dari luar negeri, seperti Karate, Yudo, Aikido, Taekwondo dan sebagainya. Selain prasarana dan sarana yang diperlukan bagi kegiatan pencak silat belum memadai, pencak silat dianggap sebagai tradisi yang ketinggalan zaman (kuno), mistis dan bias gender sebagai stigmanya. Pencak silat juga dianggap tidak berperprospektif yang mencerahkan bagi kesejahteraan pesilat (Sutantri, 2018).

Berdasarkan latar belakang ini, tim Pusat Studi Internasional Universitas Padjadjaran (Unpad) tergugah untuk melaksanakan sosialisasi tentang pentingnya pelestarian pencak silat sebagai warisan budaya bangsa dan soft power Indonesia melalui kegiatan Pengabdian kepada Masyarakat (PkM). PkM dilaksanakan dengan menggunakan metode sosialisasi yang ditujukan kepada siswa Sekolah Menengah Pertama (SMP) di Kota Bandung sebagai target. Tema pencak silat sebagai warisan budaya Indonesia bagi kegiatan sosialisasi dan dalam judul artikel telah ada dan dilakukan oleh pendahulu, namun perkaitannya dengan pencak silat sebagai sumber soft power negara Indonesia belum ditemukan atau dieksplorasi oleh pengabdi atau peneliti sebelumnya (lihat Gristyutawati, dkk,. 2012; Kriswanto, 2015; Subroto, dkk., 1996; Sutantri, 2018; Ediyono \& Widodo, 2019). Oleh karena itu pengabdian berbasis riset yang dilakukan oleh tim PkM HI Unpad adalah untuk mengisi kesenjangan (gap) tersebut. Tujuannya adalah untuk memberikan pengetahuan dan pemahaman mengenai pentingnya pencak silat sebagai warisan budaya dan sumber soft power Indonesia kepada para siswa, serta mengetahui bagaimana penerimaan dan kesediaan bertindak mereka pasca mendapatkan sosialisasi.

\section{Metode}

Target kegiatan PkM adalah pelajar SMP, perempuan dan lelaki, terutama yang telah mengikuti kegiatan pencak silat di sekolahnya. PkM dilaksanakan selama 4 bulan (JuniSeptember 2019), melalui proses penjajagan, observasi, operasi dan evaluasi. SMP 2 Bandung dipilih karena memiliki kegiatan pencak silat sebagai kegiatan ekstra kulikuler bagi pelajar. Beberapa dari mereka telah berhasil memperoleh prestasi dalam lomba pencak silat. Metode PkM yang digunakan adalah metode sosialisasi dari Mead (1972) yang salah satunya adalah pola partisipatoris (partisipatory socialization). Pola partisipatoris bersifat interaktif, komunikatif 
dua arah, dan memberikan imbalan bila berprilaku baik dan hukuman yang bersifat simbolik bila berprilaku buruk.

Sosialisasi berpola partisipatoris terdiri dari empat tahapan. Tahapan pertama, yaitu persiapan (preparatory stage), adalah tahap mempersiapkan diri target untuk mengenal dan memahami dunia sosialnya. Tahapan kedua adalah meniru (play stage), yaitu target mulai memainkan peranan sosial yang berlaku di masyarakat dalam lingkup terbatas. Tahap ketiga adalah siap bertindak ( game stage). Pada tahap ini target memainkan sendiri peran sosial secara individu maupun kolektif dalam lingkup yang lebih luas. Tahapan keempat adalah penerimaan target atas norma kolektif (generalized stage/generalized other) sebagai kematangan sosial (Mead, 1972). Setelah selesai metode Mead dilaksanakan, langkah PkM selanjutnya adalah menyebar kuesioner kepada target. Tujuannya adalah untuk mengetahui sikap dan pendapat mereka pasca sosialisasi. Kuesioner berisi pertanyaan-pertanyaan mengikuti model pengukuran Skala Likert (Likerts Scale).

\section{Hasil dan Pembahasan}

Kegiatan PkM dari tim Pusat Studi Internasional Universitas Padjadjaran (Unpad) melibatkan beberapa mahasiswa yang tengah mengikuti program KKN. Kegiatan PkM ini menggunakan metoda sosialisasi dari Mead dan penyebaran kuesioner kepada subjek target di lokasi. Kegiatan dilaksanakan dalam satu hari, namun proses keseluruhan kegiatan mengambil masa empat bulan lamanya. Model sosialisasi Mead yang digunakan terdiri dari empat tahapan proses. Berikut di bawah ini adalah deskripsi proses, hasil dan pembahasannya.

\section{Sosialisasi tahap Persiapan}

Sosialisasi tahap pertama (Gambar 1), yaitu persiapan kepada para siswa target. Dilaksanakan dengan tujuan untuk mempersiapkan para pelajar target dengan bekal pengenalan dan pengayaan pengetahuan mengenai pencak silat dan manfaatnya bagi diri sendiri, masyarakat dan negara. Materinya disampaikan dengan metode ceramah secara lisan yang dilengkapi dengan slide paparan, media video film pendek, dan peragaan-peragaan di depan para pelajar target. Penyampai materi ceramah terdiri dari 4 orang dengan latar belakang pengetahuan dan keilmuan yang berbeda.

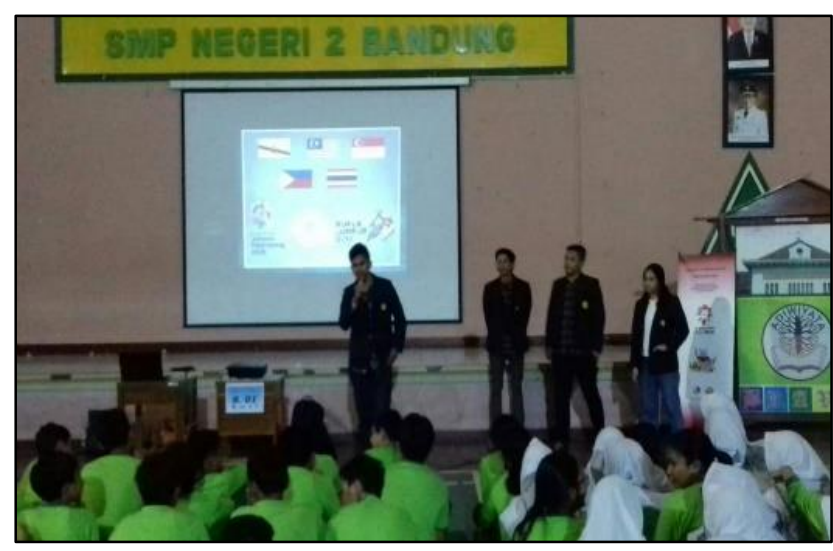

Gambar 1. Pemberian materi mengenai tema sosialisasi 
Pemateri pertama adalah dari perwakilan Pusat Studi Internasional Unpad. Materinya berupa pemaparan sejarah asal dari pencak silat; perkembangan makna dari pencak, silat dan pencak silat. Selain itu juga dikenalkan fungsi dan manfaat dari pencak silat, baik sebagai seni bela diri, sebagai olahraga kebugaran jasmani dan cabang olahraga yang dipertandingkan secara nasional dan internasional. Disampaikan pula pencak silat sebagai warisan budaya asli dan sumber kekuatan (soft power) bangsa Indonesia. Ceramah kedua disampaikan oleh dua orang mahasiswa KKN Unpad dari program studi yang berbeda. Materinya disampaikan dengan dukungan media film pendek. Pemateri dengan latar belakang Studi Hubungan Internasional memberi pengetahuan mengenai pencak silat yang telah mendunia dan dikembangkan di beberapa negara. Disambung oleh pemateri yang berlatar belakang studi Ilmu Budaya menyampaikan ragam pencak silat yang ada di daerah-daerah Indonesia. Pemateri berikut disampaikan oleh seorang mahasiswa KKN Unpad yang aktif sebagai pesilat di salah satu Padepokan Pencak Silat di Bandung. Materinya berupa pengenalan akan jurus-jurus dan kudakuda pancak silat yang disampaikan dengan peragaan-peragaan dan pertunjukan.

Pada saat ceramah berlangsung, para siswa target tampak serius menyimak namun santai dan ceria. Hal ini dikarenakan materi disampaikan dengan jenaka yang diselingi dengan tampilan gambar-gambar audio visual yang menarik dan lucu agar pesan-pesan dari tujuan sosialisasi dapat diterima mereka dengan mudah dan menyenangkan. Para pemateri sebelumnya sudah dibekali mengenai cara-cara ceramah yang efektif dan efisien serta menarik bagi target sesuai kapasitasnya, yang dalam hal ini adalah para palajar tingkat SMP. Setelah selesai ceramah, para siswa target diberi kesempatan untuk bertanya maupun mengungkapkan pendapatnya mengenai pengetahuan dan pengalamannya mengenai pencak silat. Dari pengamatan di lokasi, para pelajar target tampak serius menyimak dan juga antusias mengikuti proses pembekalan pada tahap persiapan ini.

Seperti yang diteorikan oleh Mead, tahap persiapan dialami sejak manusia dilahirkan, saat seorang anak mempersiapkan diri untuk mengenal dunia sosialnya. Dalam tahap ini, para siswa target telah lebih dulu mengenal pencak silat sebagai seni beladiri bangsa Indonesia, maupun manfaatnya bagi diri sendiri. Namun melalui kegiatan sosialisasi PkM pada tahap persiapan para siswa target diperkaya wawasannya tentang pencak silat dan kaitannya dengan soft power. Di antaranya tentang nilai-nilai dan norma-norma yang terkandung dalam pencak silat untuk dijadikan pedoman bergaul dalam masyarakat; serta tentang contoh nyata manfaat dari mendalami pencak silat tidak hanya bagi diri sendiri, tetapi juga bagi masyarakat bangsa dan negara. Khususnya terkait pencak silat sebagai sumber soft power Indonesia, sesuai dengan prasayat keberhasilan soft power dari Nye (2004), para siswa target sebagai calon anggota masyarakat digugah kesadaran dan jiwa patriotismenya untuk memberikan dukungan bagi negara di kemudian hari. Dengan demikian melalui kegiatan sosialisasi tahap persiapan ini para siswa target telah dipersiapkan dengan bekal pengetahuan mengenai pencak silat dan soft power beserta manfaatnya dan peran yang diharapkan oleh negara terhadap mereka di masa depan. 


\section{Sosialisasi pada tahap meniru dan permainan}

Sosialisasi pada tahap kedua terdiri dari gabungan tahapan meniru (play stage) dan tahapan siap bertindak (game stage). Tujuannya adalah untuk memotivasi siswa target dapat memainkan peranan sosial yang berlaku dan diharapkan masyarakat kepada mereka, individu maupun kolektif, khususnya dalam keterkaitannya dengan pencak silat.

Bentuk pelaksanaanya adalah berupa simulasi dan kuiz. Simulasi berupa permainan peran dengan beberapa skenario yang telah dipersiapkan oleh tim PkM Unpad. Skenario berisi sinopsis drama mini dengan unsur pencak silat. Siswa target dibagi menjadi beberapa kelompok, dan mendapatkan skenario berdasarkan undian untuk kemudian dimainkan oleh mereka. Setelah itu, sebagai akhir acara diadakan kuis interaktif. Kuiz berupa tebakan mengenai jurus-jurus pencak silat dan para siswa target diminta untuk memeragakannya. Acara kuiz ini dilengkapi dengan hadiah bagi pemenangnya. Hadiah yang diperoleh pemenang secara simbolis memberi pengalaman akan manfaat nyata dari suatu keberhasilan dalam kegiatan peran sosial yang melibatkan pencak silat.

Dari pengamatan di lokasi, para pelajar target tampak antusias dan bergembira mengikuti proses tahap kedua ini. Melalui simulasi dan kuiz, para siswa target dapat merasakan dan mengalami manfaat dari aspek-aspek psikomotorik, afektif dan koqnitif mereka yang didapat dari pencak silat.

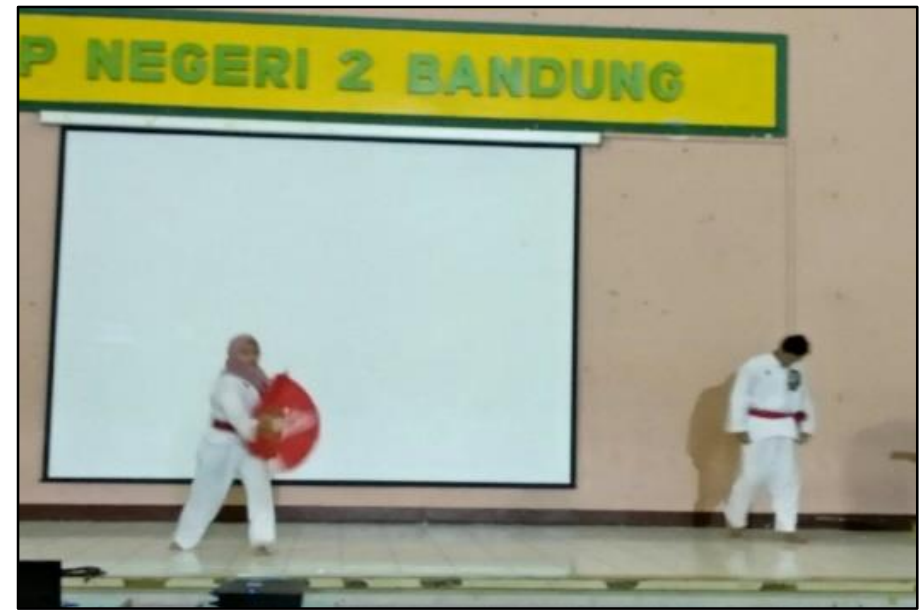

Gambar 2. Peragaan Pencak Silat sebelum simulasi

Seperti yang diteorikan oleh Mead, tahap peniruan ditandai dengan semakin sempurnanya seorang anak menirukan peran-peran yang dicontohkan atau dilakukan oleh orang dewasa dan masyarakat pada umumnya. Disusul dengan tahap permainan (Game Stage), yang mana peniruan yang dilakukan sudah mulai berkurang dan digantikan peran yang secara langsung dimainkan sendiri dengan penuh kesadaran. Bersesuaian dengan teori Mead tersebut, melalui contoh-contoh nyata (tahap peniruan) dan simulasi (Game Stage) yang melibatkan para siswa target dalam sosialisasi PkM, beberapa hal diharapkan terjadi dari diri mereka. Pertama, para siswa target mulai tergugah kesadaran posisi dirinya sebagai bagian dari bangsa Indonesia yang diharapkan peranannya dalam melestarikan pencak silat sebagai warisan budaya bangsa. Kedua, para siswa target mampu menyiapkan diri untuk berkontribusi nyata bagi mewujudkan 
pencak silat sebagai sumber soft power negara melalui kegiatan pencak silat yang tengah mereka geluti pada masa sekolah tingkat pertama hingga masa seterusnya nanti.

\section{Sosialisasi pada tahap siap bertindak}

Proses sosialisasi pada tahap ketiga yaitu kesiapan bertindak dari para siswa target yang telah menerima pembekalan pengetahuan mengenai pencak silat dan memperoleh pengalaman dari pencak silat. Tahap ini dilaksanakan dengan tujuan untuk memperoleh gambaran mengenai ada atau tidaknya motivasi, perubahan sikap atau kematangan sosial para pelajar sasaran terkait pencak silat pasca sosialisasi.

Seperti yang diteorikan oleh Mead bahwa pada tahap siap bertindak seseorang telah dianggap mampu menempatkan dirinya pada posisi masyarakat secara luas. Sesuai dengan hal ini, para siswa target sosialisasi PkM, yang telah melewati tahap persiapan, peniruan dan permainan, dianggap telah mampu menempatkan diri mereka pada posisi masyarakat secara luas dan bertindak sesuai norma yang berlaku dan sesuai kewajiban sebagai warga negara seperti yang diharapkan negara. Dalam hal ini adalah aktif melestarikan pencak silat sebagai warisan budaya bangsa dan berkontribusi bagi mewujudkan pencak silat sebagai sumber soft power negara. Untuk mengetahui hal tersebut digunakan teknik kuesioner yang dibagikan kepada 40 orang siswa target. Kuesioner berupa serangkaian pertanyaan yang dibagi ke dalam dua kategori. Kategori pertama adalah pertanyaan terbuka mengenai pengetahuan dan pengalaman siswa target terkait dengan pencak silat. Kategori kedua adalah pertanyaan tertutup mengenai materi dari kegiatan sosialisasi yang baru mereka peroleh.

\section{Hasil Kuesioner Kategori Terbuka}

Kuesioner kategori terbuka terdiri dari tujuh pertanyaan. Pertanyaan-pertanyaan ini ditujukan untuk mengetahui pengetahuan dasar para siswa target mengenai pencak silat dan bagaimana mereka menyikapi dan menekuninya. Ketujuh materi pertanyaan tersebut adalah sebagai berikut: pertama, mengenai jenis dan jurus pencak silat yang para siswa ketahui dan tekuni; kedua, mengenai pengetahuan awal para siswa mengenal dan tertarik dengan pencak silat; ketiga, tentang mengapa para siswa terarik dengan pencak silat; keempat, mengenai pengalaman para siswa dalam menekuni pencak silat; kelima, tentang perlombaan pencak silat yang diikuti para siswa; keenam, mengenai niat dan cita-cita para siswa di masa depan terkait pencak silat; dan terakhir adalah pengetahuan para siswa mengenai soft power, soft power negara dan kaitannya dengan pencak silat.

Dari hasil kuesioner yang dibagikan dan dijawab oleh para siswa target dapat diperoleh informasi mengenai pengetahuan dasar mereka mengenai pencak silat dan bagaimana menyikapi dan menekuninya kemudian. Para siswa target menyatakan mereka telah mengenal beberapa jenis dan jurus pencak silat. Jenis pencak silat yang mereka kenal antara lain Cimande dan Cikalong, serta jenis jurus-jurus, seperti jurus tangan kosong dan beberapa jurus bersenjata, khususnya yang berasal dari daerah mereka berasal dan berada, yaitu Jawa Barat. Ketertarikan awal para siswa target terhadap pencak silat didapat dari lingkungan keluarga dan lingkungan sosial di sekitar tempat tinggal mereka. Selain itu juga didapat dari media televisi dan film, serta dari kegiatan ekstra kulikuler sekolah dan dari pelajaran sekolah. 
Alasan mengapa para siswa target tertarik dengan pencak silat beragam. Antara lain, mereka menyatakan tertarik karena keindahan gerakan atau jurusan dari pencak silat, makna atau nilai kulturalnya, potensinya sebagai alat untuk bela diri dan olahraga alternatif, dan sebagai sarana sosialisasi lebih luas. Sebagian pelajar target mulai menekuni pencak silat sejak menjadi siswa SMP yang menyediakan pencak silat sebagai kegiatan ekstra kulikuler. Beberapa dari siswa target telah menekuninya sejak mereka di Sekolah Dasar. Meskipun demikian, di antara para siswa itu belum berkesempatan mengikuti turnamen pencak silat di luar lingkungan sekolahnya. Hanya satu siswa yang mengakui pernah mengikuti dan bahkan memperoleh prestasi dari pertandingan tingkat daerah.

Mengenai ada dan tidaknya niat serius dan cita-cita para siswa target di masa depan terkait dengan pencak silat yang ditekuni, hanya satu siswa yang menyatakan berniat mengembangkan pencak silat yang ditekuni dan bercita-cita menjadi pesilat professional atau atlet pencak silat Indonesia yang berprestasi. Sebagian besar siswa lainnya menyatakan tidak atau belum berpikiran masa depan mereka kelak akan berkaitan dengan pencak silat. Mereka masih menganggap pencak silat sebagai sarana olahraga kebugaran dan seni bela diri tradisonal maupun sebagai sarana rekreasi. Pengetahuan dan pemahaman para siswa mengenai pencak silat dan kaitannya dengan soft power negara tampaknya masih terbatas. Mereka mengakui baru mengenal konsep soft power dari sosialisasi PkM ini.

\section{Hasil Kuesioner Kategori Tertutup}

Kuesioner kategori tertutup ditujukan untuk memperoleh gambaran ada atau tidaknya pemahaman akan materi sosialisasi, yaitu pencak silat sebagai warisan budaya dan sumber kekuatan (soft power) bangsa Indonesia. Selain itu juga ditujukan untuk memperoleh gambaran ada atau tidaknya dan perubahan sikap atau kematangan sosial para siswa target pasca sosialisasi akan pentingnya peranan sosial mereka sebagai warga negara yang berbakti bagi masyarakat dan negara terkait pencak silat. Kuesioner terdiri dari tiga pertanyaan utama, dan masing-masing dengan beberapa anak pertanyaannya sebagai pilihan jawaban. Jawaban berjenjang yang menunjukkan tingkat persetujuan dengan pilihan: Sangat Setuju; Setuju; Ragu-ragu; Tidak Setuju; Sangat Tidak Setuju. Dua pertanyaan untuk jawaban berjenjang yang menunjukkan tingkat kebersediaan dengan pilihan: Sangat Bersedia, Bersedia, Ragu-ragu, Tidak Bersedia, dan Sangat Tidak Bersedia.

Pertanyaan pertama adalah tentang pencak silat sebagai warisan budaya Indonesia dengan lima anak pertanyaan. Jawaban yang diperoleh dapat dilihat gambarannya pada Charta 1. Tentang pencak silat sebagai hubungan manusia dengan Tuhan, semua siswa target menjawab sangat setuju (100\%). Tentang pencak silat sebagai hubungan manusia dengan manusia, semua siswa menyatakan sangat setuju (100\%). Tentang pencak silat sebagai hubungan manusia dengan alam, sebagian besar siswa menjawab setuju (80\%), dan beberapa siswa lagi menyatakan sangat setuju (20\%). Tentang pencak silat sebagai olah fisik, mental, etika dan estetika, para siswa menjawab sangat setuju (40\%), setuju (55\%), dan ragu-ragu (5\%). Tentang pencak silat sebagai gaya hidup bangsa Indonesia perlu diajarkan sejak usia dini, para siswa menjawab sangat setuju (40), setuju (35\%), dan ragu-ragu (25\%). 


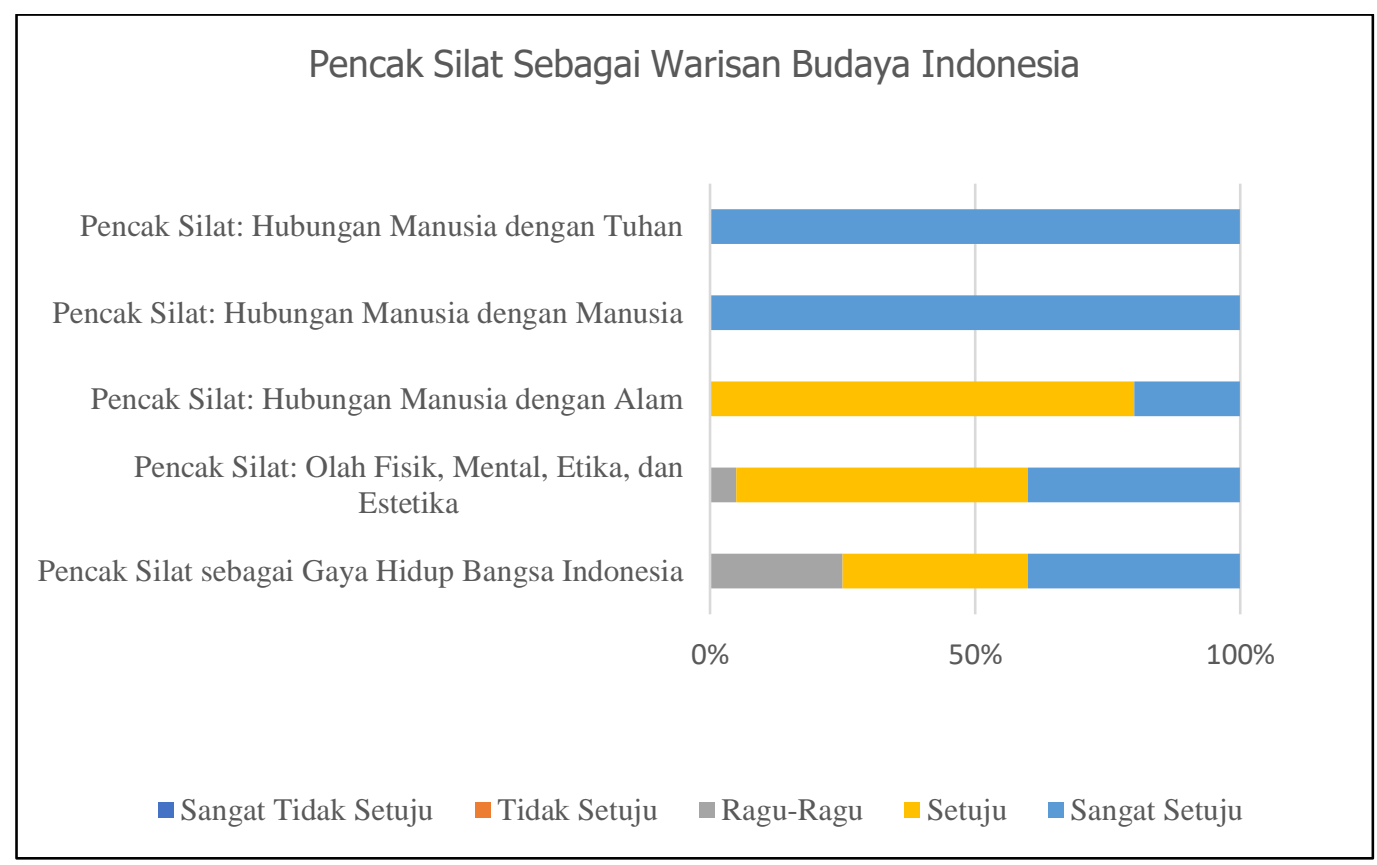

Charta 1. Penerimaan siswa tentang pencak silat sebagai warisan budaya Indonesia Sumber: diolah oleh Tim PKM Unpad

Dengan demikian, berdasakan hasil kuesioner ini, penerimaan mayoritas siswa dengan tingkat kesetujuan terhadap pencak silat sebagai warisan budaya Indonesia dengan semua dimensi di dalamnya, menunjukkan bahwa pengetahuan mereka telah terkayakan dari kegiatan sosialisasi. Hasil ini bersesuaian dengan tujuan dari teori sosialisasi tahap pertama dan kedua dari Mead.

Semua siswa target menjawab sangat setuju (100\%) mengenai pencak silat sebagai hubungan multi dimensi antara manusia dengan Tuhan, manusia dengan manusia, manusia dengan alam. Seperti yang dikemukakan oleh Sucipto (2009), pencak silat bertujuan untuk pembinaan mental spiritual, terutama untuk mewujudkan budi pekerti yang luhur. Pencak silat membentuk pribadi yang kokoh, tidak hanya pembinaan terhadap aspek olahraga, seni dan bela diri semata, melainkan dapat mengembangkan watak luhur, sikap kesatria, percaya diri sendiri dan takwa kepada Tuhan Yang Maha Esa. Sementara, mengenai pencak silat sebagai olah fisik, mental, etika dan estetika, serta pencak silat sebagai gaya hidup bangsa Indonesia, mayoritas siswa target menyatakan setuju. Menurut Sucipto pula, aspek olahraga dan beladiri akan membantu seseorang untuk mendapatkan kesehatan jasmani, semangat dan pemberani, aspek seni berkaitan dengan estetika, hal ini bisa membuat jiwa menjsadi indah sedangkan aspek spiritual dapat meningkatkan religiusitas (Sucipto, 2009). Dengan demikian, meskipun melalui ceramah yang singkat dalam pelaksanaan sosialisasi PkM para siswa target dapat menangkap materi yang disampaikan dan paham pentingnya pencak silat bagi bangsa Indonesia.

Pertanyaan kedua adalah tentang pencak silat sebagai sumber soft power dengan tiga anak pertanyaan. Jawaban yang diperoleh dapat dilihat gambarannya pada Charta 2 . Tentang pencak silat sebagai sumber nilai-nilai bangsa, para siswa menyatakan setuju (60\%), dan raguragu (40\%). Jawaban tentang pencak silat sebagai sumber budaya bangsa Indonesia, para 
siswa menyatakan: sangat setuju (40\%), Setuju (40\%), dan ragu-ragu (20\%). Jawaban tentang pencak silat sebagai instrumen hubungan internasional, para siswa menyatakan: sangat setuju $(15 \%)$, setuju (50\%), Ragu-ragu (35\%).

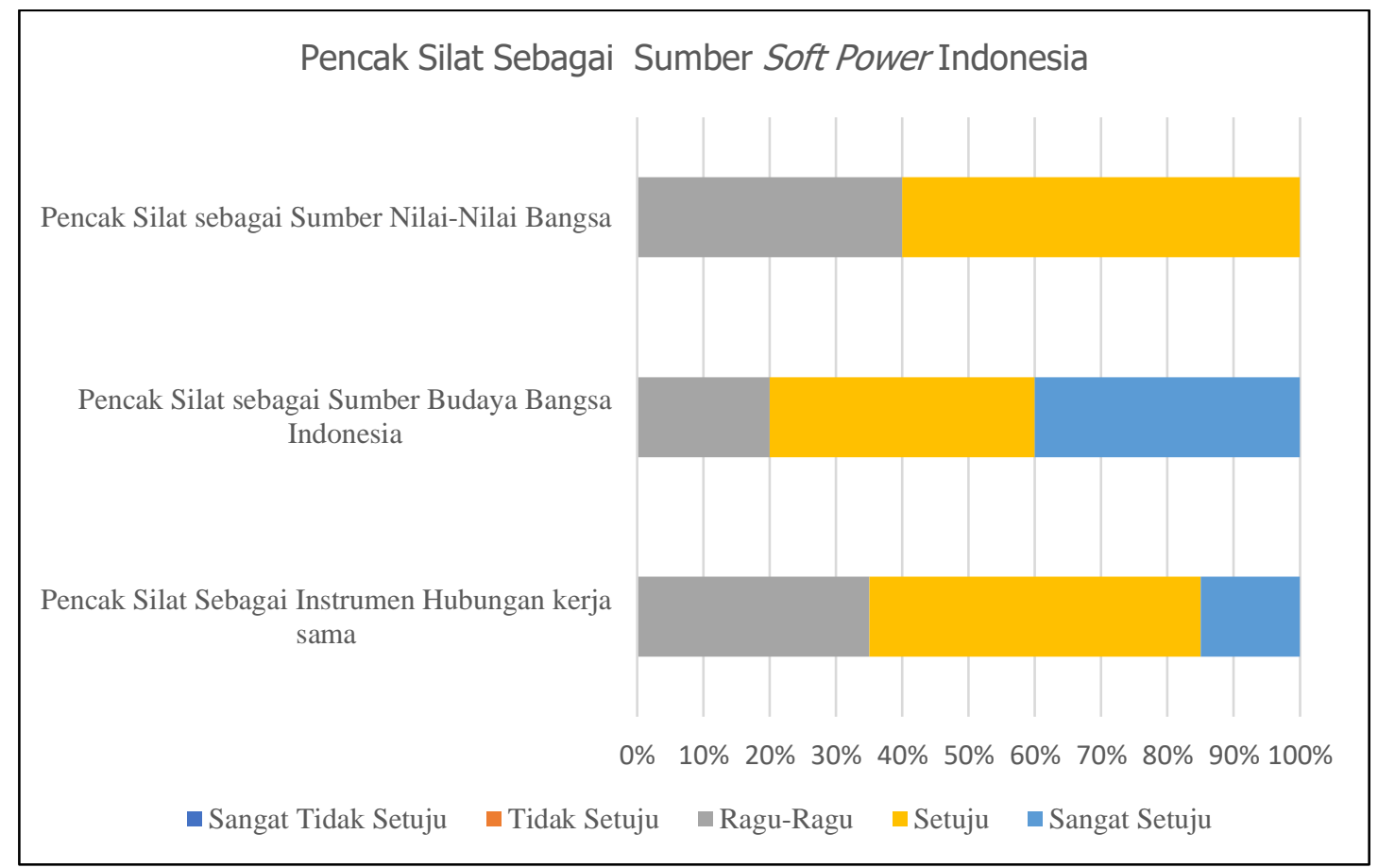

Charta 2. Penerimaan siswa tentang pencak silat sebagai sumber soft power Sumber: diolah oleh Tim PKM Unpad

Dari hasil kuesioner ini, melalui tingkat kesetujuan yang diberikan oleh sebagian besar para siswa target tentang pencak silat dengan semua dimensi di dalamnya tersebut, menunjukkan pengetahuan dan ingatan mereka yang didapat dari kegiatan sosialisasi telah diterima dan terkayakan mengenai penting dan manfaatnya pencak silat sebagai sumber soft power Indonesia. Hasil ini juga bersesuaian dengan tujuan dari teori sosialisasi tahap pertama, kedua dan ketiga dari Mead.

Sumber soft power, menurut Nye (2004), harus memiliki kemenarikan bagi target. Dengan demikian, pencak silat Indonesia setidaknya harus memiliki unsur kemenarikan pula. Sebagai nilai-nilai bangsa, pencak silat mengandung nilai-nilai kearifan lokal yang menarik dan tidak bertentangan dengan nilai-nilai luhur umum yang berlaku di seluruh dunia (worldview). Sebagai sumber budaya, pencak silat mengandung unsur-unsur materi, mental, estetika dan etika yang menarik sebagai gaya hidup keseharian bagi bangsa Indonesia maupun bagi bangsa lain. Sebagai instrumen hubungan kerja sama, pencak silat menghubungkan manusia dengan Tuhan, manusia dengan manusia dan manusia dengan alam yang unik dan menarik. Harmonisasi dari ketiga hubungan tersebut dapat menjadi landasan bagi suatu kerja sama antar manusia sebangsa dan antarbangsa yang bertaqwa, berimbang dan bermartabat (Rachman, dkk., 2019). Tampaknya para siswa target telah dapat memahami kemenarikan dari pencak silat sebagai sumber soft power Indonesia, oleh karena itu mereka memberikan kesetujuan 
untuk memberikan dukungan, meskipun terdapat tingkat keraguan yang cukup signifikan dari para siswa. Hal ini dapat dimaklumi mengingat konsep soft powerbelum akrab ditelinga mereka.

Pertanyaan ketiga adalah tentang dukungan terhadap pencak silat sebagai warisan budaya dan sumber kekuatan (soft power) bangsa Indonesia dengan dua anak pertanyaannya. Jawaban yang diperoleh dapat dilihat gambarannya pada Charta 3. Tentang kesediaan menjadikan pencak silat sebagai sumber prestasi pribadi dan kolektif, yang menyatakan sangat bersedia (20\%), bersedia (40\%), tidak bersedia (10\%) dan sisanya menyatakan ragu-ragu (30\%). Terakhir adalah tentang kesediaan berpartisipasi dalam mempromosikan dan memajukan pencak silat sebagai warisan budaya dan soft power Indonesia, sebagian menyatakan setuju (60\%) dan sebagian lagi menyatakan sangat setuju (40\%).

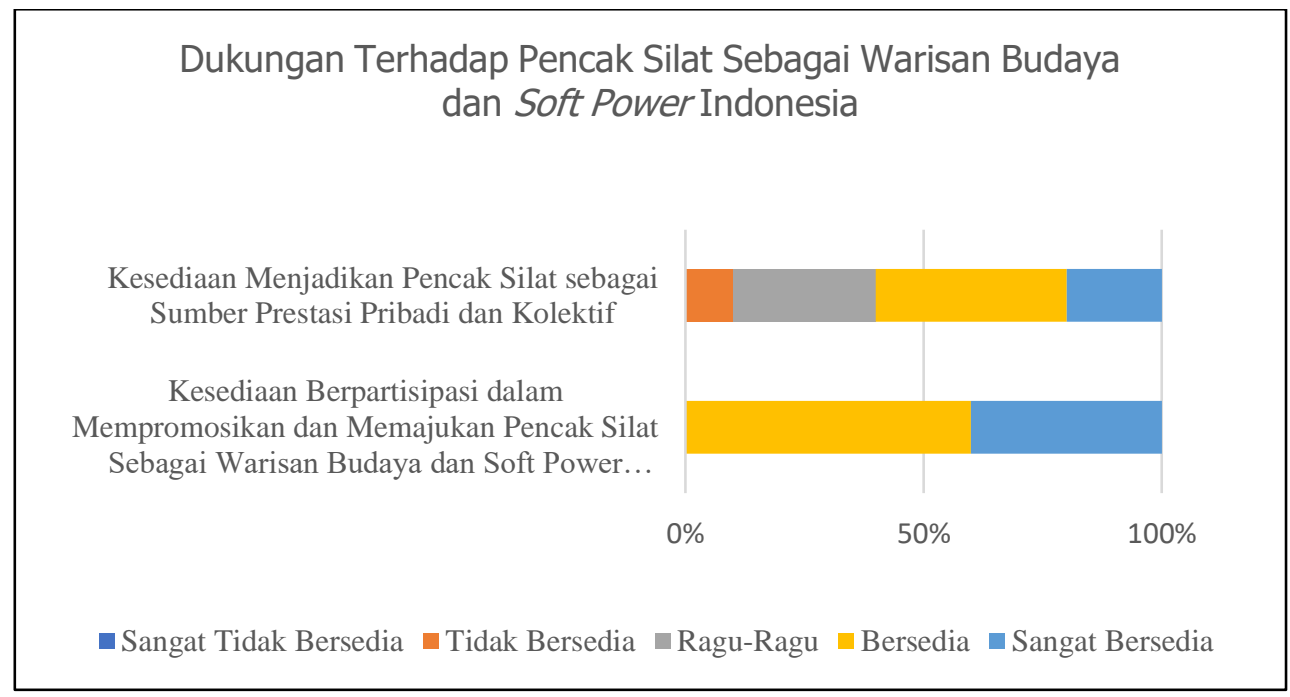

Charta 3. Kesediaan siswa tentang dukungan terhadap pencak silat sebagai warisan budaya dan soft power. Sumber: diolah oleh Tim PKM Unpad

Dari hasil kuesioner ini, melalui tingkat kebersediaan yang diberikan oleh para siswa dalam mendukung pencak silat sebagai warisan budaya dan sumber soft power Indonesia, menunjukkan bahwa pada pasca sosialisasi telah ada motivasi, perubahan sikap atau kematangan sosial para siswa target. Hasil ini bersesuaian dengan tujuan dari teori sosialisasi tahap keempat dari Mead. Menurut Mead, eksistensi seseorang dalam suatu komunitas terjadi melalui suatu proses interaksi dirinya dengan masyarakat dalam komunitas tersebut. Seseorang harus berpartisipasi dalam berbagai posisi sosial dalam masyarakat dan baru setelah itu ia dapat menggunakan pengalamannya untuk mengambil perspektif orang lain dan dengan demikian menjadi 'sadar' (p. 176). Wujud sadar salah satunya adalah motivasi yang menjadi salah satu faktor penentu dan mendorong tingkah laku manusia untuk berubah atau sebaliknya sesuai dengan harapan komunitas dan norma-norma yang berlaku dalam komunitas itu (Astutik, 2017).

Pada pasca sosialisasi PkM, meskipun ada ketidaksediaan dan keraguan dari beberapa siswa untuk menjadikan pencak silat sebagai sumber prestasi pribadi dan kolektif, namun mayoritas setuju untuk ikut berpartisipasi dalam mempromosikan pencak silat sebagai warisan 
budaya dan sumber soft power Indonesia seperti yang diharapkan negara dan masyarakat dalam menjalankan peran sosial mereka sebagai warga negara yang berbakti.

\section{Kesimpulan}

Pencak silat yang telah diakui oleh UNESCO sebagai warisan budaya tak benda pada tahun 2019 telah memberi arti besar bagi bangsa Indonesia tidak hanya berupa pengakuan bahwa pencak silat sebagai warisan budaya asal Indonesia tapi juga sebagai sumber kekuatan (soft power) bangsa Indonesia. Hal ini telah dipahami oleh para siswa target, khususnya sebagai hasil pengayaan pengetahuan dari kegiatan sosialisasi PKM Unpad. Kepahaman mereka dinyatakan melalui persetujuan dan ketidakraguan tentang pencak silat sebagai warisan budaya dan sebagai sumber soft power Indonesia yang perlu dilestarikan dan ditingkatkan. Pada tingkat kematangan sosial dan tindakan, sebagian dari mereka menyatakan kesediaan untuk menjadikan pencak silat sebagai sumber prestasi pribadi dan kolektif dan mayoritas bersedia berpartisipasi dalam mempromosikan dan memajukan pencak silat sebagai warisan budaya dan soft power Indonesia. Dengan demikian kelestarian pencak silat sebagai warisan budaya Indonesia dan pencak silat sebagai sumber soft power Indonesia dapat diharapkan dari para siswa sebagai generasi penerus. Meskipun tujuan dari sosialisasi PKM ini telah tercapai, namun rekomendasi perlu diajukan, yaitu agar kegiatan sosialisasi dengan tema yang sama dapat diselenggarakan secara berkala dan berkesinambungan. Jumlah target diperbanyak dan metodenya ditingkatkan kepada pemberdayaan.

\section{Referensi}

Astutik, D. (2017). Telaah Kritis Gagagasan Sosialisasi Mead: Self, Mind, Society. Habitus: Jurnal Pendidikan, Sosiologi, \& Antropologi, 1(1), 61-79. https://doi.org/10.20961/habitus.v1i1.18856

Ediyono, S., \& Widodo, S. T. (2019). Memahami Makna Seni dalam Pencak Silat. Panggung: Jurnal Seni Budaya, 29(3). 299-313, http://dx.doi.org/10.26742/panggung.v29i3.1014

Gristyutawati, A. D., Purwono, E. P., \& Widodo, A. (2012). Persepsi Pelajar Terhadap Pencak Silat Sebagai Warisan Budaya Bangsa Sekota Semarang Tahun 2012. Journal of Physical Education, Sport, Health and Recreation, 1(3), 129-135. https://doi.org/10.15294/active.v1i3.443

Kemenlu.go.id. (2019). Pencak Silat ditetapkan sebagai Warisan Budaya Tak Benda Dunia oleh UNESCO. (Artikel web) Diambil di: Kementrian Luar Negeri Republik Indonesia: https://kemlu.go.id/portal/id/read/890/berita/pencak-silat-ditetapkan-sebagai-warisanbudaya-tak-benda-dunia-oleh-unesco

Kriswanto, E. S. (2015). Pencak Silat, Sajarah dan Perkembangan Pencak Silat, Teknik-teknik dalam Pencak Silat, Pengetahuan Dasar Pertandingan Pencak Silat. Bantul Yogyakarta: Pustaka Baru Press.

Mead, G. H. (1972). Mind, Self, and Society from the Standpoint of a Social Behaviorist. Chicago: University of Chicago.

Muhyi, M., \& Purbojati. (2014). Penguatan Olahraga Pencak Silat sebagai Warisan Budaya Nusantara. Jurnal Budaya Nusantara, 1(2), 141-147. https://doi.org/10.36456/b.nusantara.vol1.no2.a415

Nye, J. S. (2004). Soft Power: the Means to Success in World Politics. . New York: Public Affairs.

Rachman, J. B., Aditiany, S., Suryadipura, D., Utama, B. P., Sutantri, S. C., \& Novalini, M. R. (2019). Asian Games 2018: Kajian Soft Power Pada Perhelatan Mega Olahraga. Bandung: CV. Pustaka Utama Bandung (Anggota IKAPI).

Subroto, J., \& Rohadi., M. (1996). Kaidah-Kaidah Pencak Silat Seni yang Tergabung dalam IPSI. Solo: CV Aneka.

Sucipto, M. P. (2009). Materi Pokok Pencak Silat. Jakarta: Universitas Terbuka. 
Sutantri, S. C. (2018). Diplomasi Kebudayaan Indonesia dalam Proses Pengusulan Pencak Silat sebagai Warisan Budaya Takbenda UNESCO. Jurnal IImu Politik dan Komunikasi , 8(1), 28-47. doi:0.34010/jipsi.v8i1.876

Welianto, A. (2020). Kompas.com. Pencak Silat: Arti, Sejarahnya dan Teknik Dasar (Artikel web). Diakses di: https://www.kompas.com/skola/read/2020/03/06/080000569/pencak-silat--artisejarahnya-dan-teknik-dasar?page=all. 